\section{TUBERCULOSIS DEATHS AND THE WAR}

BY

\author{
PERCY STOCKS, M.D., D.P.H. \\ Medical Statistical Officer, General Register Office
}

Tuberculosis mortality has been described as a social barometer, and this it is in more than one sense. "The actively tuberculous population, numbering somewhere about a quarter of a million persons, is very sensitive to environmental changes such as periods of unusually cold weather, industrial depression, increased crowding due to various causes, shortage of certain foods, enhanced stress of living conditions produced by war, and even, it seems likely, to psychological stresses affecting large bodies of people. The immediate effects of cold winters and influenza epidemics, for example, are reflected in the deaths from respiratory tuberculosis oscurring in the March quarters, which are given below for England and Wales in the period 1924-38:

\begin{tabular}{|c|c|c|c|c|c|}
\hline $\begin{array}{l}1924 \\
1925 \\
1926 \\
1927 \\
1928\end{array}$ & $\begin{array}{l}\mathbf{9 , 6 8 0} \\
\therefore \quad 9,126 \\
. \quad 8,517 \\
\quad 9,240 \\
. \quad 8,444\end{array}$ & $\begin{array}{l}1929 \\
1930 \\
1931 \\
1932 \\
1933\end{array}$ & $\begin{array}{rr}\ldots & \mathbf{1 0 , 1 4 0} \\
\ldots & \mathbf{8 , 2 2 7} \\
\ldots & \mathbf{9 , 0 1 8} \\
\ldots & 8,244 \\
. & \mathbf{8 , 9 1 2}\end{array}$ & $\begin{array}{l}1934 \\
1935 \\
1936 \\
1937 \\
1938\end{array}$ & $\begin{array}{ll}\ldots & \mathbf{7 , 4 2 9} \\
\ldots & \mathbf{6 , 9 4 7} \\
\therefore & \mathbf{6 , 8 9 2} \\
\therefore & \mathbf{7 , 1 4 7} \\
\therefore & \mathbf{6 , 0 0 4}\end{array}$ \\
\hline
\end{tabular}

The bold figures indicate levels higher than in either the preceding or succeeding year, and, of the six quarters in which they occurred, those of 1924,1929 , and 1931 were unusually cold, while those of $1927,1929,1933$, and 1937 had rather severe influenza epidemics. The tuberculous have not the normal reserves of strength to meet additional stresses and strains, and they react very quickly by a rise in death rate. If the increase in ceaths is considerable or if it is long continued and not accompanied by a corresponding rise in incidence of new cases, the reservoir of persons in an advanced stage of the disease may be thereby so much reduced in numbers that a rapid fall in deaths at once follows when the stresses are removed. This probably accounts for the rise and fall in deaths from respiratory tuberculosis noticed at the beginning of wars, though it does not account for the increase in deaths from tuberculous meningitis which also appeared early in the present war.

In another sense tuberculosis deaths are an index of social conditions because if changes in the latter are such as to increase the incidence of active disease this is inevitably followed by a rise in death rates, and in so far as the new infections are of the meninges and nervous system this increase becomes quickly evident. In the case of new respiratory disease, however, the effect on deaths may be so long delayed as to appear as a seconcary wave after the initial wave referred to above has almost passed. In the present war, so far, we have experienced the initial wave due to hastened deaths of the already tuberculous, and, starting rather later, a wave due to fresh meningitic infections. It will be seen below that each of these waves reached a peak in 1941 and that a rapid fall towards the normal has since been registered in the first half of 1942 ; but a resumption of harder conditions may yet produce further temporary increases of the same kind. Furthermore, the reservoir of tuberculous persons is probably greater now than at the onset of the war owing to increased incidence of ractive disease in 1940 and 1941 , and if that is so a return to the normal peacetime trend of deaths is likely to be delayed.

For a long period preceding 1939 we had become accustomed to a continuous decline in tuberculosis deaths, and it is necessary to bear this in mind when estimating the effects of the war. When deaths have merely returned to the 1938 level this will not mean that the debt has been paid, because had there been no war there is no reason why the steady decline should not have progressed, bringing 1942 deaths much below the 1938 level. In order to obtain a proper base level of peace- time expectation it is reasonable to assume that the rate of proportional annual decline experienced during the pre-war period would have continued year by year. The figures below designated as "expected" are based on that assumption, but they are necessarily only approximate owing to the impossibility of taking into account at this stage any changes in the population at risk which may have been occasioned by the war. It must suffice to say that the deaths here recorded comprise all deaths in England and Wales, whether of civilians or of noncivilians.

\section{Respiratory Tuberculosis}

The average numbers of deaths from respiratory tuberculosis, classified according to the method of assignment in use up to 1939 and occurring in the first and second halves of the year, in triennial periods from 1924-6 to $1936-8$ were as follows:

\begin{tabular}{|c|c|c|c|c|}
\hline \multirow[b]{2}{*}{ Period } & \multicolumn{2}{|c|}{ First Half of Year } & \multicolumn{2}{|c|}{ Second Half of Year } \\
\hline & $\begin{array}{l}\text { Average } \\
\text { Deaths } \\
\text { Occurring }\end{array}$ & $\begin{array}{c}\text { Fall from } \\
\text { Previous Period } \\
(\%)\end{array}$ & $\begin{array}{c}\text { Average } \\
\text { Deaths } \\
\text { Occurring }\end{array}$ & $\begin{array}{c}\text { Fall from } \\
\text { Previous Period } \\
(\%)\end{array}$ \\
\hline $\begin{array}{l}1924-6 \\
1927-9 \\
1930-2 \\
1933-5 \\
1936-8\end{array}$ & $\begin{array}{l}17,299 \\
17,102 \\
15,866 \\
14,357 \\
12,578\end{array}$ & $\begin{aligned} &- 1.1 \\
&= 7.2 \\
&= 9.5 \\
&-12.4\end{aligned}$ & $\begin{array}{l}14,458 \\
13.662 \\
13,041 \\
11,690 \\
10,618\end{array}$ & $\begin{array}{r}5.5 \\
=4.5 \\
-10.4 \\
-\quad 9.2\end{array}$ \\
\hline
\end{tabular}

Between 1931 and 1939 the population was increasing by about $1.5 \%$ every 3 years, so, adding this to the average percentage increase in deaths in the last two triennial intervals, it is evident that the crude death rates must have been falling by about $4 \%$ annually during the immediate pre-war period. Assuming no substantial changes in the population at risk since, a continuance of a $4 \%$ fall annually in the deaths was to be expected if there had been no war, and the actual and expected deaths up to mid-1942, classified throughout according to the revised International List and method of assignment in force from 1940, may be compared, as below:

\begin{tabular}{|c|c|c|c|c|c|c|}
\hline \multirow{2}{*}{ Years } & \multicolumn{3}{|c|}{ First Half } & \multicolumn{3}{|c|}{ Second Half } \\
\hline & Expected & Registered & Excess & Expected & Registered & Excess \\
\hline $\begin{array}{c}1936-8 * \\
1939 \\
1940 \\
1941 \\
1942\end{array}$ & $\begin{array}{r}1 \overline{1,243} \\
10,793 \\
10,361 \\
9,947\end{array}$ & $\begin{array}{l}12,199 \\
11,859 \\
13,322 \\
13,504 \\
11,828\end{array}$ & $\begin{array}{r}-76 \\
+\quad 616 \\
+2,529 \\
+3,143 \\
+1,881\end{array}$ & $\begin{array}{l}9 \overrightarrow{497} \\
9,117 \\
8,752 \\
8,402\end{array}$ & $\begin{array}{r}10,305 \\
9,683 \\
10,338 \\
10,129 \\
-\end{array}$ & $\begin{array}{r}-186 \\
+\quad 1,221 \\
+1,377\end{array}$ \\
\hline
\end{tabular}

* Average.

The first half of 1939 registered a substantial excess over the expected figure and also over the first half of 1938, when the deaths numbered 11,412. This cannot be explained by a cold winter or by influenza, but whether it had anything to do with the depression and anxieties of the post-Munich period is a matter for conjecture. The increase over 1938 was almost confined to males between 40 and 70 and females aged 30 to 34. Leaving 1939 out of account, the excess of deaths over expectation in 1940 totalled 3,750 , in 1941 about 4,500 , and in the first half of 1942 about 1,900, giving an aggregate excess up to June, 1942, of some 10,000 deaths. Part of the excess in the first halves of 1940 and 1941 was probably due to the exceptionally cold winters of those years; but they differed from 1929 in having no appreciable influenza epidemic, and it seems unlikely that more than 2,000 of the excess in the two years can have been caused by the climatic conditions. It may be estimated, therefore, that a total excess of some 8,000 deaths is attributable, so far, to the war. The first half of 1942 showed pronounced improvement over the two preceding years, the number of deaths returning to the 1939 level, though still some 1,900 above the number which would have been reached if the pre-war rate of decline had continued.

The increase was relatively greatest among children under 15 , at which ages the deaths are few in number. Other age groups specially affected were men of 35 to 44 and women of 20 to 24 . The improvement in the first half of 1942 was apparent in every group, and particularly among females of 15 to 19 and 35 to 44 . 
Tuberculosis of Meninges and Central Nervous System

The trend of deaths during the 1924-38 pe-iod is indicated by the figures below:

\begin{tabular}{|c|c|c|c|c|}
\hline \multirow[b]{2}{*}{ Period } & \multicolumn{2}{|c|}{ First Half of Year } & \multicolumn{2}{|c|}{ Second Half of Year } \\
\hline & $\begin{array}{l}\text { Average } \\
\text { Deaths } \\
\text { Occurring }\end{array}$ & $\begin{array}{c}\text { Fall from } \\
\text { Previous Period } \\
(\%)\end{array}$ & $\begin{array}{l}\text { Average } \\
\text { Deaths } \\
\text { Occurring }\end{array}$ & $\begin{array}{c}\text { Fall from } \\
\text { Previous Period } \\
(\%)\end{array}$ \\
\hline $\begin{array}{l}1924-6 \\
1927-9 \\
1930-2 \\
1933-5 \\
1936-8\end{array}$ & $\begin{array}{l}1,708 \\
1,535 \\
1,420 \\
1,189 \\
1,029\end{array}$ & $\begin{array}{r}-10.1 \\
=7.5 \\
=16.3 \\
-13.5\end{array}$ & $\begin{array}{r}1,282 \\
1,128 \\
1,074 \\
860 \\
746\end{array}$ & $\begin{array}{r}-12.0 \\
=4.8 \\
=19.9 \\
-13.3\end{array}$ \\
\hline
\end{tabular}

Allowing for the population increase as before, a rate of fall of at least $5 \%$ annually was to be expected, leading to the following comparison with the actual deaths registered:

\begin{tabular}{c|c|c|c|c|c|c}
\hline \multirow{2}{*}{ Years } & \multicolumn{2}{|c|}{ First Half } & & \multicolumn{2}{c}{ Second Half } \\
\cline { 2 - 7 } & Expected & Registered & $\begin{array}{c}\text { Excess or } \\
\text { Defect }\end{array}$ & Expected & Registered & $\begin{array}{c}\text { Excess cr } \\
\text { Defect }\end{array}$ \\
\hline $1936-8^{*}$ & - & $1,062+$ & - & - & $770 \dagger$ & - \\
1939 & $959 \dagger$ & $969+$ & +10 & $695 \dagger$ & 715 & +20 \\
1940 & 911 & 1,047 & +136 & 660 & 839 & +179 \\
1941 & 865 & 1,422 & +557 & 627 & 944 & +317 \\
1942 & 822 & 1,169 & +347 & 596 & - & - \\
\hline
\end{tabular}

* Average. † Classified acco:ding to method used from 19,0 onwards.

The increase in deaths from this form of tuberculosis began in 1940 and reached its maximum in the first half of 1941 with an excess over expectation of about 550 , the excess then falling to about 350 in the first half of 1942. The total excess of deaths probably attributable to war conditions up to June, 1942 , was over 1,500

The sex-age distribution shows that while every group was affected, males aged 20 to 24 , children under 10 , and young adult females registered the highest relative increases. The improvement in the first half of 1942 was limited to children, males aged 20 to 24 , and young adult females, other groups showing further increases.

\section{Tuberculosis of Other Sites}

To complete the picture, the trend of deaths in the pre-war period for all other forms of tuberculosis led to an expectation of an annual fall of about $6 \%$, the numbers of deaths being as follows:

\begin{tabular}{|c|c|c|c|c|c|c|c|c|}
\hline \multirow[b]{2}{*}{ Period } & \multicolumn{4}{|c|}{ First Half of Year } & \multicolumn{4}{|c|}{ Second Haitf of Year } \\
\hline & \multicolumn{2}{|c|}{$\begin{array}{c}\text { Average } \\
\text { Deaths } \\
\text { Occurring }\end{array}$} & \multicolumn{2}{|c|}{$\begin{array}{c}\text { Change from } \\
\text { Previous Period } \\
(\%) .\end{array}$} & \multicolumn{2}{|c|}{$\begin{array}{c}\text { Average } \\
\text { Deaths } \\
\text { Occurring }\end{array}$} & \multicolumn{2}{|c|}{$\begin{array}{c}\text { Change from } \\
\text { Previous Period } \\
(\%)\end{array}$} \\
\hline \multirow[t]{2}{*}{$\begin{array}{c}1924-6 \\
1927-9 \\
1930-2 \\
1933-5 \\
1936-8 \\
-\end{array}$} & \multicolumn{2}{|c|}{$\begin{array}{l}2,659 \\
2,233 \\
2,013 \\
1,670 \\
1,394\end{array}$} & \multicolumn{2}{|c|}{$\begin{array}{r}-16.0 \\
-9.9 \\
-17.0 \\
-16.5\end{array}$} & $\begin{array}{l}2,304 \\
1,938 \\
1,659 \\
1,349 \\
1,211\end{array}$ & & \multicolumn{2}{|c|}{$\begin{array}{l}-15.9 \\
-14.4 \\
-18.7 \\
-10.2\end{array}$} \\
\hline & Expected & $\operatorname{Reg}$ & stered & Excess & Expected & Reg & stered & Excess \\
\hline $\begin{array}{c}1936-8 * \\
1939 \\
1940 \\
1941 \\
1942\end{array}$ & $\begin{array}{l}1, \overline{216} \dagger \\
1,143 \\
1,075 \\
1,010\end{array}$ & & $\begin{array}{l}77 \dagger \\
03 \dagger \\
10 \\
152 \\
12\end{array}$ & $\begin{array}{r}- \\
+87 \\
+267 \\
+377 \\
+402\end{array}$ & $\begin{array}{c}\overline{1,067 \dagger} \\
1,093 \\
943 \\
886\end{array}$ & & $\begin{array}{l}207+ \\
994 \dagger \\
188 \\
218\end{array}$ & $\begin{array}{r}- \\
+27 \\
+185 \\
+275 \\
-\end{array}$ \\
\hline
\end{tabular}

* Average. † Classifiet according to method used from 1940_onwards.

An increase in deaths was again evident early in the war, and the excess over expectation has increased progressively, although the number of deaths fell sligl:ily in the first half of 1942. The total excess from 1940 to June, 1942, probably attributable to war conditions was about 1,500 deaths.

For all forms of tuberculosis the cost of the war up to mid-1942 may thus be estimated as about 11,000 deaths, and the initial waves of respiratory and meningeal tuberculosis deaths seem now to be rapidly ceclining. But the improvement which was to be expected from the normal downward trend of the pre-war period has yet to be overtaken, and a secondary, perhaps more lasting, wave may yet appear as a delayed result of the increased incidence in active disease of the respiratory form which is believed to have occurred in 1940-1.

\section{ARTIFICIAL RESPIRATION AT SEA}

BY

\author{
G. H. GIBBENS, M.B., M.R.C.S. \\ Surg. Lieut., R.N.V.R.
}

In England we are apt to think .that nobody questions the supremacy of the method of artificial respiration introduced by Sir Edward Sharpey-Schafer in 1904. Yet Silvester's method is preferred in Eastern Europe and in Nordic countries, and even in an official British publication (see Refs.) Cordier writes: "All experimenters agree that Silvester's method introduces in the respiratory tract of the apparently dead subject the biggest volume of air." The figures of lung ventilation by these two methods (Table I) are, to say the least, inconclusive, and the almost ideological frenzy in the attacks of the opposing advocates leaves the impression that it is the nationality of the promoter which determines the choice of method.

TABLE I.-Lung Ventilation in c.cm.

\begin{tabular}{l|c|c|c|c|c}
\hline Method & $\begin{array}{c}\text { Schafer } \\
\text { (1908) } \\
\text { Buton-Opitz } \\
(1922)\end{array}$ & Cordier & $\begin{array}{c}\text { Killick and } \\
\text { Eve } \\
(1933)\end{array}$ & $\begin{array}{c}\text { Liljestrand } \\
\text { et al. } \\
(1913)\end{array}$ & $\begin{array}{c}\text { Bruns } \\
(1927,1930 ;\end{array}$ \\
\hline $\begin{array}{l}\text { Silvester's } \\
\text { Schafer's }\end{array}$ & 175 & $\begin{array}{c}200-250 \\
100-150\end{array}$ & $\begin{array}{c}200 \\
500-550\end{array}$ & $\begin{array}{c}190 \\
\text { under 30 }\end{array}$ & $\begin{array}{c}200-280 \\
\text { under 30 }\end{array}$ \\
\hline
\end{tabular}

But the subject is not academic: it is urgently practical. Many otherwise uninjured men are rescued after only a short immersion and yet do not survive. This is undoubtedly because the normal methods of artificial respiration are not very efficient, need many skilled men, and are so tiring that they are not carried out thoroughly or for long enough. It was a relief to read of Eve's rocking method, which can be practised by unskilled men, efficiently and with little fatigue. Unfortunately, the impression has been created that this method requires special apparatus and is not suitable for emergencies outside hospitals. It does not seem to have become widely known. Killick and Eve (1933) have given detailed figures which show the rocking stretcher's superiority over other methods, and it is eminently practicable at sea. It is the object of this article to emphasize the simplicity of the method and to urge its adoption in ships.

\section{Principle of Artificial Respiration by Rocking}

In 1932 Eve wrote: "Formerly I regarded the breathing thorax as a concertina bellows; my present work suggests that it resembles rather a cylinder and piston. In older men the cylinder wall is often rigid and is scarcely used in respiration at rest. Hence in artificial respiration it seems much better to exploit the piston action of the diaphragm rather than to try to compress the rigid walls of the cylinderleaving the piston flapping passively up and down and thus frustrating much of one's efforts to squeeze air in and out of the trachea." Essentially the method consists in laying the patient on a stretcher, which is pivoted about the middle on a trestle, and rocking up and down rhythmically so that the abdominal viscera push the flaccid diaphragm alternately up and down.

\section{Apparatus}

Simple apparatus is required. Although Keevil (1934) extemporized successfully, there is little time for invention when a drowning man is on deck. (Scott (1941) quotes Canadian statistics which show that if artificial respiration is given to men within a minute of electrocution $90 \%$ recover ; if after 6 minutes, only $10 \%$ recover. In other words, drowning is as urgent a condition as a spurting artery.) The essential apparatus consists of (1) a plane to which the patient can be fastened; (2) a fulcrum ; (3) a stop to prevent the plane sliding to and fro on the fulcrum.

1. A ladder or a door might be used, but for present purposes we can assume that a stretcher is available. The man may be held 